\title{
The Application of Zero-translation Technique in Intercultural Communication
}

\author{
Qinqin Zhu ${ }^{1}$ \\ New Star Institute of Technology Application ${ }^{1}$ \\ Hefei City, Anhui Province, China, 230031 \\ ahqinqin@126.com
}

\author{
Mei Wang ${ }^{2}$ \\ New Star Institute of Technology Application ${ }^{2}$ \\ Hefei City, Anhui Province, China, 230031 \\ e-mail: pbxywm@163.com
}

\author{
Lan $\mathrm{Hu}^{3} *$ \\ New Star Institute of Technology Application ${ }^{3}$ \\ Hefei City, Anhui Province, China, 230031 \\ e-mail: 308984545@qq.com \\ *corresponding author
}

\begin{abstract}
With the rapid development of world economy, people have increasingly enlarged their communications with others and the intercultural communications among countries are becoming more and more frequent and important. Translation, as a means of bridging intercultural communication has been discussed heatedly by linguists and translators. Zerotranslation discussed in this paper, as a new translation strategy, has been widely applied in the intercultural communication. This paper studies the definition of zero-translation and its wide application, with an expectation to enhance the understanding of this new translation technique and improve the intercultural communication.
\end{abstract}

Keywords-zero-translation;

translation

technique; intercultural communication

\section{INTRODUCTION}

In the 21 st century, global economy and cultural diversity have been the general trends of our world. Digitalization and information technology have brought human society into an age of information expansion. This kind of fantastic spud creates human beings' globalization, especially in economy, finance and trade. The economic globalization has become a nonreversible trend, and none of nations in this world can or would like to hide themselves out of this trend behind this provincial wall. The globalization development trend in material world will cause revolution in cultural field. The result of economic globalization will undoubtedly bring the intercommunications among different cultures.

Translation, as the act or process of rendering what is expressed in one language or set of symbols by means of another language or set of symbols" [1], has played a huge role in the intercultural communication.

The existing of zero-translation is reasonable and it accords with the Principle of Least Effort and the theory of Functional Equivalence. Principle of least effort is an important principle in pragmatics, but it is also applicable to translation especially for translators and users. Most zero-translated words can co- exist with their Chinese equivalents. For example, "E-Mail" and “电子邮件”(E-mail), “IT” and “现代信息技术”(Modern Information Technology), “MTV” and “音乐电视”(Music Television). The two writing forms are both available in Chinese. "E-Mail" is an acronym by shortening word groups "Electric Mail", "IT" by shortening "Information Technology", "MTV" by shortening "Music TV" in the original language. The English native speakers take the acronyms for serving least effort. The translators also transfer these acronyms by following the same principle in English-Chinese translation and therefore zero-translated words come into Chinese language.

\section{DEFINITION OF ZERO-TRANSLATION}

In China, the concept "zero-translation" was first put forward by Du Zhengming [2] in his article "A Socio-linguistic and Intercultural Perspective on Free, Literal, and ZeroTranslation". But he translated it into Chinese as Bu Yi. He pointed out that because $\mathrm{Bu} \mathrm{Yi}$ is opposite to translation, while translation is converting meanings. Thus transliteration can be regarded as $\mathrm{Bu} \mathrm{Yi}$, as well as transplanting some $\mathrm{SL}$ words directly into TL.

Professor Qiu Maoru [3] proposes the term "zerotranslation" in his article "Translatability and Zero Translation". He translated it into Chinese as Ling Fan Yi, which is what we refer to here. It refers to transferring the SL words directly to the TL text without any change on its phonology and graphology. Professor Qiu points out that this new concept contains two levels of implications: 1) the words and phrase in the SL remain deliberately not translated; 2) the corresponding word or words exist in the TL, but are not used to translate the words or words in the SL.

Luo Guoqing [4] defines "zero-translation" in narrow and broad senses. In narrow sense, zero-translation is just transference, which refers to the coming directly of SL words and graphs into TL text, let readers comprehend TL text in the SL culture. In broad sense, zero-translation refers to both 
transference and transliteration. Luo thinks that zero translation is not $\mathrm{Bu} \mathrm{Yi}$ and it is a kind of culture translation by the readers because the translators transfer the image and language symbols to the TL from the SL, and bring readers to perceive and understand in the SL context. Thus, zero-translation breaks the obstacles of language symbols, and it is a new translation method which is quite different from the traditional ones.

Zhang Nanfeng [5] defines zero-translation differently from what we discuss usually. He defines it as the culturespecific item of the SL text which is disappearing in the TL text. This is different from ellipsis. Because ellipsis does not omit the meaning of SL text, while zero-translation omits culture-specific item as well as meaning.

Sun Yingchun drew "zero-translation" in his book Verbal Forest of Translation in 2001. He does not define it, just say it is one of transliteration and image translation. From this we can see that translators have accepted the concept of zerotranslation since 2001 .

Also, there are some authorities who deny that it is a translation and consider that it is the translators' job to translate, to explain. The existing of zero-translation is reasonable, and it appears because of the influence of cultural transmission. As the development of intercultural communication, cultural exchanges are more and more frequent among every country. Thus, learning each other's culture becomes an absolutely necessary part in translation. Zero-translation is a kind of translation. It is a special translation strategy which brings SL words fully or partly into $\mathrm{TL}$ and it is different from $\mathrm{Bu} \mathrm{Yi}$, and has no cause-and-effect relations with untranslatability. It is not a lazy way to translate. It introduces SL words directly into TL with the SL culture introduced to the TL at the same time.

Professor Liu Mingdong [6] has accepted the concept of zero-translation, and he classifies zero-translation into two categories: absolute zero-translation, relative zero-translation. Absolute zero-translation is to reach the effect of translatability by not using TL words, and the common methods are ellipsis and transference. Relative zero-translation is to express the SL meaning by using target words in different methods, and the common methods are transliteration, sound-meaning combination translation, complementary translation, image translation, literal translation with notes, adaptation.

\section{APPLICATION OF ZERO-TRANSLATION}

Because of the newly appearing of zero-translation, it has not been widely used in all kinds of media and literary styles. Zero-translation is most frequently used in newspapers, magazines and internet. With the popularization of zerotranslation, we can find that zero-translation is also used by TV broadcasters, reporters, teachers, and many other people too. In literary style, zero-translation is mostly frequently used in technology style. It is sometimes used in novel, drama and other literary styles too.

\section{A. Zero translation used in different media 1) Newspapers}

In Xin'an Daily, there is a report, which is about a newly found planet, example (1):

……这颗行星……正围绕一颗名为“Gliese 581”的红 矮星运转, 被命名为“Gliese 581c”。尽管 Gliese 581c…… 但红矮星 Gliese 581 比太阳…… (Xin'an Daily, Apr. 26, 2007, A02) (.....This planet...around a red dwarf called Gliese 581 ", was named "Gliese 581 c".Although Gliese 581 c...But the red dwarf star Gliese 581 than the sun...)

In this report, Gliese 581 is directly transferred from English without translation, which is easier accepted by readers.

Example (2) is a report from Guangming Daily. It is about a band from America. The reporter quotes the band name NOFX, name of the band members (FatMike) directly by zero-translation, which is a better way to introduce this band.

Example (2):

美国最受年轻人喜爱的朋克乐队 NOFX 将……, NOFX 将于 4 月 13 日登陆北京，与香港荔枝王 (KingLyChee)硬核摇滚劲旅…… NOFX 乐队成立于 1983 年, 至…… NOFX 目前……而乐队主唱 FatMike 主理的 独立厂牌 FatWreckChords 也是摇滚乐领域里的标志性厂 牌之一。荔枝王(KingLyChee)则……2003 年, Beyond 乐队……的独立厂牌 PolarBear 旗下 ……(Guangming Daily, Apr. 6, 2007) (The American most popular band among the young, punk band NOFX will... NOFX is to appear in Beijing on April 13, together with Hong Kong king of litchi (KingLyChee) the hardcore rock giants....NOFX band was founded in 1983, to... NOFX now...The independent label FatWreckChords of the fontman FatMike runs is one of the iconic brand in the field of rock and roll. Lich king (KingLyChee) is....In 2003, the band Beyond ...the independent labels PolarBear,...)

\section{2) Magazines}

\section{Example (3):}

DROOG 的商店: DROOG 是一个设计基金会, 由 Gijs 和 Renny 夫妇创办 $\cdots \cdot \cdots$ DROOG 在 $\cdots \cdots$.... KESSELS KRAMER 广告公司……KESSELS KRAMER 广告公司用 DV 记录了...... (Art World, Aug 2006, Page: 47) (DROOG store: DROOG design is a foundation, founded by Gijs and Renny couple...DROOG in...KESSELS KRAMER advertising company...KESSELS KRAMER advertising company with a DV record...)

\section{3) Internet}

In internet, there are really many zero-translation words. We will just cite some examples of them.

Example (4):

德意战八看点: 模特队 PK 教练组, 巴拉克对话托 蒂（ http://2006.qq.com/a/20060704/ 000103.htm ） (Eight aspects of German and Italian match: model team PK coaching staff, Barak dialogue with Totti) 
The word "PK" has been frequently used in Chinese, which means "player kill" in games. In sports, PK is "Point Kick". With the population of the program "super voice", PK has been widely used in all kinds of media. Example (6) is just one example in internet.

\section{Example (5):}

上周，上海大众宣布新一代 POLO 下线……POLO 升级版——POLOGP, 预计于 6 月中旬前后上市…… (http://www.whb.com.cn/cs/t20060602_962875.htm )( Last week, Shanghai Volkswagen announced a new generation of POLO offline...POLO upgrade - POLOGP, is expected to debut around the middle of June....)

\section{4) TV, Radio, Movie}

Besides newspaper, magazine and internet, zerotranslation is also popular in TV, Radio and Movie etc. When we listen carefully, we can find them. Because of the difficulties of recording, we just mention it without cite any examples here.

\section{B. Zero translation used in different literary styles \\ 1) Scientific literary style}

In scientific aspect, different industry has different sense for specific terms. Thus, to translate those terms correct is difficult. In case of mistranslating, it is better to use the zerotranslation. The words after zero-translation are easier to be understood than translated into TL, then why do we waste our time and energy to translate them? Thus zero-translation is popular in scientific literary style. Example (9) is zerotranslation used in the specialty of medicine.

\section{Examples (6):}

Whatever factors are given as the causes of cancer, the underlying cause of all cancer is DNA or RNA mutation. DNA is the substance of genes that contains the hereditary traits of an organism... DNA itself is made from a sequence or pattern of four bases. These bases are adenine, quinine, cytosine, and thymine. The arrangement of these bases on the DNA molecule determines the proteins that each cell can produce. We call this arrangement of bases on DNA the genetic code. To carry out protein synthesis, DNA manufactures a messenger, RNA (ribonucleic acid), which enters the cytoplasm and attaches itself to the ribosomes (where protein is synthesized) located on the endoplasmic reticulum...(Grasp Medical English, 1991: 264)

\section{Translated as:}

尽管有各种因素被认为是致癌的原因, 但最重要的 原因是 DNA (脱氧核糖核酸) 和 RNA (核糖核酸) 的突 变。DNA 是基因中含有生物遗传特性的物质。…… DNA …… DNA 制造信使 RNA, RNA ……(Although there are various factors considered to be the cause of the cancer, but the most important reason is that the DNA (deoxyribonucleic acid) and RNA (ribonucleic acid) mutation. DNA is the genes found in biological characteristics of the
material.......DNA...Manufacturing messenger RNA, DNA, RNA...)

Words underlined are DNA, RNA, gene, among which DNA, RNA are transferred into Chinese with notes bracketed at first. Gene is the transliterated word. In fact, when we say DNA or RNA, it is easier to understand than 脱氧核糖核酸 (deoxyribonucleic acid)or 核糖核酸(ribonucleic acid). At the same time, it is laborsaving, space and time saving.

Example (7) is zero-translation used in the specialty of computer.

\section{Example (7):}

DOS, Windows, $\cdots \cdot$ COBOL, FORTRAN, BASIC, PASCAL, C, LISP. Each language is for specific use, for example, COBOL is convenient for programs in finance and accounting, FORTRAN is good for scientific calculations, PASCAL is widely used in engineering designs, $\mathrm{C}$ is suited for automatic control engineering, LTSP is exclusive for articial intelligence research, BASIC is usually used in simple programs, doing basic arithmetic and logical computation and printing. Assembly is a machine-oriented language. Programs written in an assembly language can work faster than programs written in high-level languages-FORTRANS, PASCAL, LISP, etc.

\section{Translated as:}

DOS, Windows …...COBOL, FORTRAN, BASIC, PASCAL, C, LISP。每一种语言都为某一种特定的用途 而设计，例如, COBOL 对金融和会计方面的程序是方便 的, FORTRAN 对科学计算很有用, PASCAL 广泛用于工 程设计, $\mathrm{C}$ 适合自动控制工程, LISP 专门用于人工智能研 究, BASIC 通常用于简单的程序, 做些基本的算术和逻辑 运算和打印。汇编语言是面向机器的语言。用汇编语言编 写的程序运行速度比用高级语言——FORTRAN,

PASCAL, LISP 等编写的程序快。(Wang Youcheng, 1997: 379) (DOS, Windows...COBOL and FORTRAN, BASIC, PASCAL, C and LISP. Every language is designed for a particular purpose, for example, a COBOL to the financial and accounting aspects of the program is convenient, FORTRAN is very useful to scientific computing, PASCAL is widely used in engineering design, $\mathrm{C}$ is suitable for automatic control engineering, LISP is specifically used for artificial intelligence research, BASIC is typically used for simple program, some BASIC arithmetic and logic operations and print. Assembly language is a language for machine. Programs written in assembly language run faster than that in a high-level language, such as FORTRAN, PASCAL, and LISP.

When we refer to computer language, it is a custom that we just use the English acronyms instead of speaking full of the words and translating them. Thus, zero-translation is widely applied in computer specialty.

\section{2) Report}

When we translate English to Chinese, we like to use zero-translation. However, when we translate Chinese into 
English, we also use zero-translation sometimes. Here we will just omit the examples because of too many.

\section{3) Novel}

It is not so often to see zero-translation used in novel. However, we still find some of them. Here we just cite one example.

Example (8):

……刚喝了一日, 手机响了, ......她继续说道: “......我姓徐, 是一个 hunter, …...”(Shanghai Houniao, 2005: 100) 大唐广告? 这是一家非常有名的 Local 策划公 司, 代理着数十个著名品牌。(ibid: 101)“所以我只是做做 Freelance, 自由职业者多好……? ”(ibid: 115) “这是公司 最大的项目, 我作为办事处 CEO …… (ibid: 163) 我最好 的朋友是个 GAY, ……? (ibid: 87) (.......Just drink a mouthful, the phone rang,...She continued: "...... my name is $\mathrm{xu,}$ was a hunter,..."(Shanghai Houniao, 2005:100) datang ads? This is a very famous Local planning company, agent for dozens of famous brand.(ibid: 101). "so I just do some Freelance, how good the freelancers...?"(ibid: 115). "This is the company's biggest project, I, as CEO,....... (ibid: 163) my best friend is a GAY,...? (ibid: 87))

Novels of modern society are closely connected with the development of society, thus there are many fashion words used by zero-translation.

Words used in these two examples like "GAY, ejaculation, vamp" are expressed like euphemism to avoid embarrassment by speaking words directly in Chinese. This is a good function for zero-translation used in novels.

\section{4) Drama}

In drama, transliteration of zero-translation is used quite often, because names of people and organizations, etc are easily understood when transliterated or by other means of zero-translation. We just omit examples here, because it is easy to find in any drama.

\section{IV.CONCLUSION}

As a new strategy in the translation field, zero-translation meets the intellectual need of people in cultural communication to some extent. Zero-translation is still a kind of translation. It is a special translation strategy which brings SL words fully or partly into TL and it is different from $\mathrm{Bu} \mathrm{Yi}$, and has no cause-and-effect relations with untranslatability. It is not a lazy way to translate. It introduces SL words directly into TL with the SL culture introduced to the TL at the same time. Under the circumstance of appearance of new terms and concepts, zero translation is regarded as a measure of expediency. So it is of great theoretical and practical significance to study zero translation in the system of translation. It is of great value to make an analysis of the concept and characteristics of zero translation in translation system. It is a good translation method to change the partial untranslatability to translatability. Zero-translation breaks the separation of languages, improving the communications and exchanges among different languages, making languages come to mingle with each other. This is also a good method to learn each other's culture.

\section{REFERENCES}

[1] Hornby Mary Snell, "Translation Studies-An Integrated Approach"[M] Shanghai: Shanghai Foreign Language Education Press, 2001, pp. 39-40.

[2] Guo Jianzhong. "Culture and Translation”[C].Beijing:China Translation and Publishing Corporation, 2000, pp.26.

[3] Qiu Maoru.Translatability and Zero-translation[J].Chinese Translators Journal, vol.139, Jan. 2001, pp.24-27.

[4] Luo Guoqing.On the concept of zero-translation[J].Shanghai Journal of Translators For Science and Technology, 2005(S1), pp.88-91.

[5] Zhang Nanfeng. Translation Criticism between China and The West[M] Beijing : Qsinghua University Press, 2004, pp199-200.

[6] Liu Mingdong. On Zero-translation[J].Chinese Science\&Technology Translators Journal,vol. 143, Jan. 2002, pp.40-42. 